\title{
REPRODUCTION OF BALTIC COD, GADUS MORHUA (ACTINOPTERYGII: GADIFORMES: GADIDAE), IN THE GOTLAND BASIN: CAUSES OF ANNUAL VARIABILITY
}

\author{
Maris PLIKSHS ${ }^{1 *}$, Hans-Harald HINRICHSEN ${ }^{2}$, Didzis ELFERTS ${ }^{1,4}$, Ivo SICS ${ }^{1}$, \\ Georgs KORNILOVS ${ }^{1}$, and Friedrich W. KÖSTER ${ }^{3}$ \\ ${ }^{1}$ Institute of Food Safety, Animal Health and Environment "BIOR”, Riga, Latvia \\ ${ }^{2}$ GEOMAR, Kiel, Germany \\ ${ }^{3}$ Technical University of Denmark, National Institute of Aquatic Resources, Charlottenlund, Denmark \\ ${ }^{4}$ University of Latvia, Faculty of Biology, Riga, Latvia
}

\begin{abstract}
Plikshs M., Hinrichsen H.-H., Elferts D., Sics I., Kornilovs G., Köster F.W. 2015. Reproduction of Baltic cod, Gadus morhua (Actinopterygii: Gadiformes: Gadidae), in the Gotland Basin: Causes of annual variability. Acta Ichthyol. Piscat. 45 (3): 247-258.
\end{abstract}

Background. The Gotland Basin spawning ground is one of three main spawning areas of Baltic cod, Gadus morhua Linnaeus, 1758. The threshold water parameters for cod development are the salinity exceeding $11 \%$ and the oxygen level above $2 \mathrm{~mL} \cdot \mathrm{L}^{-1}$. Such conditions are only present when the $11 \%$ isohaline is above the 2 $\mathrm{mL} \cdot \mathrm{L}^{-1}$ isooxygen. In such situation the water volume between the isolines is called the "suitable reproduction volume". When the position of the isolines is reversed, the salinity and the oxygen level of the water layer demarcated by them are below the required thresholds and as such the water is unsuitable for the cod development. We refer to it as the "unsuitable reproduction volume". The main aim of the presently reported study was to examine whether variations in suitable and unsuitable reproduction habitat estimates could explain the fluctuations in cod recruitment.

Material and methods. The suitable and unsuitable reproduction volumes in the Gotland Basin were estimated based on single point observations at three oceanographic monitoring stations using the contouring software Balthypsograph. To test the spatial hydrological heterogeneity in the Gotland Basin we used 15 observations during 1969-1995 on four stations in each of two transects. The oceanographic monitoring and demersal trawl research survey data from 1974-2012 have been used in analyses.

Results. The sufficient reproduction conditions in the southern Gotland Basin persisted only until 1981. In later decades the reproduction potential of the Gotland Basin has decreased. The latest major North Sea water inflows in 1993 and 2003 in the Central Gotland Basin formed the suitable reproduction volume below the layers where cod eggs are floating. A significant relation between the recruit abundance and suitable and the unsuitable reproduction volumes was found only for the Southern Gotland Basin $(P<0.03)$.

Conclusions. We demonstrated that single-point estimates sufficiently quantify the reproduction conditions in the Gotland Basin and thus can be used for estimation of the reproduction volumes. The unsuitable reproduction volume concept can be used as an ecological indicator for egg survival probability in the Gotland Basin. However, it is too premature to re-define the concept of the suitable reproduction volume because it is applicable only to the Gotland spawning ground.

Keywords: fish, Baltic Sea, eastern Baltic cod, recruitment, suitable reproduction volume, unsuitable reproduction volume

\section{INTRODUCTION}

Atlantic cod, Gadus morhua Linnaeus, 1758, is a temperate marine fish that spawns in saline water layers of the continental shelf and produces pelagic eggs. The conditions in the Baltic, with a surface salinity of
$7 \% 0-8 \%{ }^{* *}$ and bottom salinity up to $10 \% 0-17 \%$, are marginal for marine species. This generally confines cod spawning to four deep areas: the Bornholm Basin, the Gdańsk Deep, the Gotland Basin, and to a lesser extent the Słupsk Furrow (Bagge et al. 1994). As a result, cod

\footnotetext{
" Correspondence: Dr. Maris Plikshs, BIOR, pārtikas drošības, dzīvnieku veselības un vides zinātniskais institūts, Daugavgrivas iela 8, LV-1048, Rīga, Latvia, phone: +37167610766, fax:+37167616946, e-mail: (MP) maris.plikss@bior.lv, (H-HH)hhinrichsen@geomar.de, (DE) didzis.elferts@lu.lv, (IS) ivo.sics@bior.lv, (GK) georgs.kornilovs@bior.lv,(FWK)fwk@aqua.dtu.dk.

** In the wake of the growing criticism of the Practical Salinity Scale concept (and especially PSU as a "unit"), Acta Ichthyologica et Piscatoria is in favour of expressing salinity in parts per thousand (\%), regardless if a direct of indirect method was employed to determine the water salinity.
} 
eggs in the Baltic Sea are concentrated in deep waters below a permanent halocline (Grauman 1984, Wlodarczyk and Horbowa 1997, Makarchouk and Hinrichsen 1998). Due to the irregularity of water exchange between the Kattegat and the Baltic Sea and to limited vertical mixing, the hydrological conditions in the cod spawning grounds and their egg concentration areas significantly vary. Periods between the inflows are characterised by oxygen depletion and decrease of salinity. Therefore, the volume of water that provides minimum environmental conditions for spawning and successful egg development as well as for survival has been referred to as the reproduction volume (RV) (Plikshs et al. 1993, MacKenzie et al. 2000). For practical reasons we will call it the suitable reproduction volume (SRV) later in the text. Recent publications (Plikshs et al. 1993, MacKenzie et al. 2000) define the threshold values of the SRV as $>11 \%$ salinity and $>2 \mathrm{~mL} \cdot \mathrm{L}^{-1}$ oxygen content. Such conditions are only present when the $11 \%$ isohaline is above the $2 \mathrm{~mL} \cdot \mathrm{L}^{-1}$ isooxygen and the SRV is the water volume between the isolines. It has been demonstrated that the actual salinity regime is the primary factor determining the vertical distribution and fertilization of eggs, whereby critical oxygen levels have effects on egg survival (Wieland et al. 1994, Nissling and Vallin 1996, Nissling and Westin 1997). However, the original definition of the SRV has been criticised, as it does not account for the effects of actual oxygen content "inside" the volume. Experimental studies revealed that egg survival increased if oxygen content increased from 2 to $5 \mathrm{~mL} \cdot \mathrm{L}^{-1}$ (Wieland et al. 1994). Nevertheless, the SRV contributes significantly to explanation of the variability in recruitment success of Baltic cod (Sparholt 1996, Jarre-Teichman et al. 1997, Heikinheimo 2008, Margonski et al. 2010). These analyses were performed for the entire population of eastern Baltic cod. The Baltic Sea, however, is characterized by spatial and vertical heterogeneity and critical environmental factors determining reproductive success and stock-recruitment relations can differ between spawning areas (Berner et al. 1989, Lišev and Lablajka et al. 1989, Köster et al. 2001, 2003).

The Gotland Basin spawning ground is the easternmost spawning area of the Baltic Sea (Fig. 1). Historical analyses have shown that the production of abundant generations of cod in the Baltic was associated with successful reproduction in the Gotland Basin (Lablaika and Uzars 1983, Kosior and Netzel 1989, MacKenzie et al. 2000, Anonymous 2013). Although during recent decades the role of the Gotland Basin in the production of cod offspring is marginal, it is important to understand the mechanisms of the formation of suitable environmental conditions for cod reproduction in the basin. Therefore, the principal aim of the presently reported investigation was to examine whether variations in the basin's specific reproduction volumes, they quantitative measures, and the physical characteristics could explain the fluctuations in cod recruitment in the Gotland Basin.

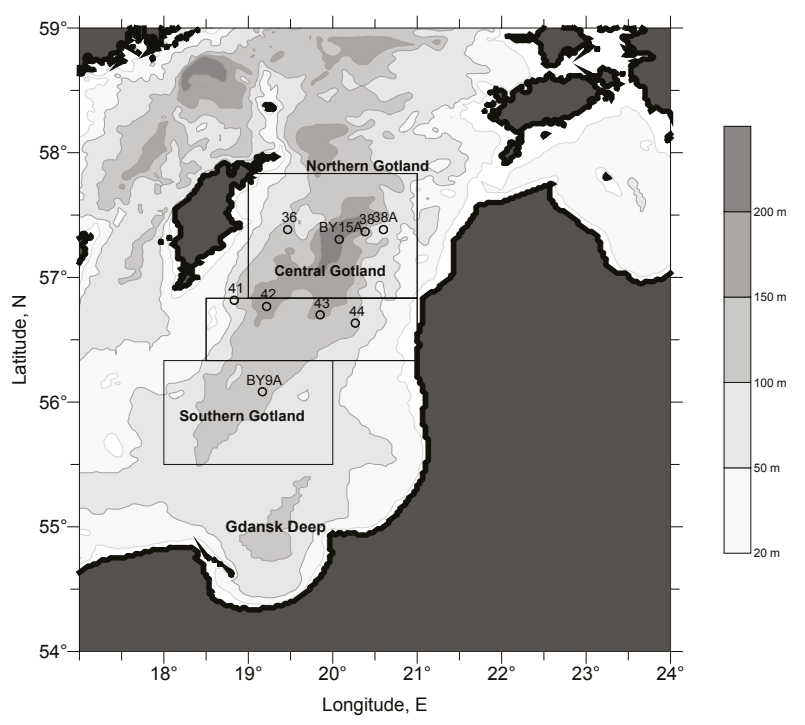

Fig. 1. Eastern Baltic Sea; Hydrological monitoring stations in the Gotland Basin; Squares indicate calculation areas for the suitable (SRV) and unsuitable (URV) reproduction volume for cod, Gadus morhua, based on single station observations: BY15A, 43, and BY9A (first method); The stations 36, BY15A, 38, 38A, and $41,42,43,44$ represent two oceanographic observations transects used for suitable (SRV) and unsuitable (URV) reproduction volume calculation by second method

\section{MATERIAL AND METHODS}

The suitable reproduction volume of Baltic cod, Gadus morhua, is defined as the water volume characterised by salinity above $11 \%$ and oxygen above $2 \mathrm{~mL} \cdot \mathrm{L}^{-1}$ (when the isohaline is above the isooxygen). It should be emphasized, however, that during the last decades such conditions have rarely been observed in the Gotland Basin. Thus, the long-term quantitative estimates of the suitable reproduction volume for the basin are difficult to derive for stagnation periods as for the majority of years no such volume was observed. In such case the suitable reproduction volume estimate is set equal to 0 .

Aeration and improvement of the salinity regime in the Gotland Deep is mainly related to major inflows of North Sea/Kattegat waters (Matthäus 2006). These events also determine the formation of the suitable reproduction volume of cod (SRV). Schematically its formation is shown in Fig. 2. During periods of advection of saline and oxygenated water masses from the Kattegat into the Gotland Basin, the salinity increases below the halocline while oxygen only increases in the near bottom layers and decreases in the intermediate layers. This is caused by the vertical displacement of less dense 'old' water masses. Such dynamic patterns determine the formation of SRV and can be observed in two distinct layers - the upper and the lower. Depending on the amount and density of water masses penetrating into the Gotland Basin there may occur more or less expressed deviations from the above presented pattern either in particular areas or in the whole basin. 


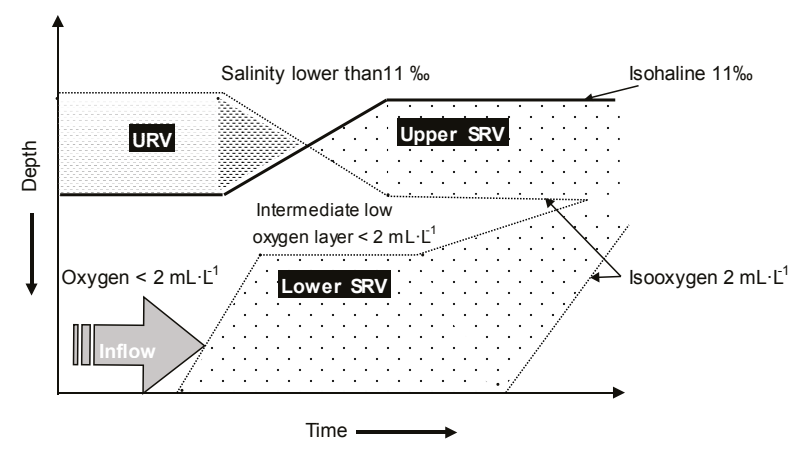

Fig. 2. Simplified schematic dynamics of isooxygen $2 \mathrm{~mL}$. $\mathrm{L}^{-1}$ and isohaline $11 \%$ o during major inflows after prolonged stagnation period in the Gotland Basin; URV = unsuitable reproduction volume, $\mathrm{SRB}=$ suitable reproduction volume (for Baltic cod, Gadus morhua)

During stagnation periods, the isooxygen $2 \mathrm{~mL} \cdot \mathrm{L}^{-1}$ usually is located above the isohaline $11 \%$. The thickness of this layer varies from year to year, depending on the duration of stagnation. Hence, we suggest to refer to it as the unsuitable reproduction volume (URV) (Fig. 2) the water volume demarcated by salinity lower than $11 \%$ and oxygen below $2 \mathrm{~mL} \cdot \mathrm{L}^{-1}$ in the water layer between $80-120$ $\mathrm{m}$ depth, e.g., with both parameters (inside such volume) being outside of the necessary requirements for successful cod egg development. This is a habitat where early development of the spawned cod eggs can be adversely affected. Taking into account the size and the condition of the spawning stock (larger females produce larger and more buoyant eggs then smaller ones) and that during stagnation periods viable cod eggs are observed (Grauman 1984, Nissling et al. 1994), this hypothesis suggests that if the URV is smaller the cod eggs have higher probability of survival and production of viable larvae. Such assumption also allowed constructing continuous time series of quantitative indices of the environmental conditions in the Gotland Basin where SRV is observed less frequently, especially in the northern part.

Calculation of SRV and URV based on single point observation (first method). Extended data series of the SRV during cod spawning time (February, May, and August) were calculated annually for the southern and central Gotland Basin based on data provided by the Latvian Institute of Food safety, Animal Health and Environment (BIOR) oceanographic monitoring and on single point observations at 3 stations (Fig. 1): BY9A, BY15A, and 43. The contouring software Balthypsograph (Wulff and Anderson, University of Stockholm) was used for the volume estimations by the hypsographic function for the Baltic Proper derived from a gridded $5^{\prime} \times 5^{\prime}$ (longitude $\times$ latitude) bathymetric database by Stigebrandt (1987) and Stigebrandt and Wulff (1987). This function quantifies the volumes of water below horizontal surfaces at given depth levels. In a similar way also the URVs were calculated annually.

Estimation of SRV and URV based on spatially disaggregated oceanographic stations (second method). The hydrographic data used for this study consisted of 15 monthly observations in the Gotland Basin between Feb- ruary 1969 and September 1999 on two transects of the Central Gotland Basin: the northern one, with stations 36, BY15A, 38, and 38A and the southern one, with stations 42,43 , and 44 delimited by the $80 \mathrm{~m}$ isobath (Fig. 1). This method is able to calculate basin-wide trends of oxygen concentration and salinity at different vertical levels and thus is able to provide spatial variability of the cod spawning environmental conditions. On average, the spatial resolution was about 30 nautical miles in latitude and 15 nautical miles in longitude. The survey data were used to calculate the thickness of the reproduction layer of Baltic cod, Gadus morhua, with respect to its classical definition (salinity $>11 \% ; \mathrm{O}_{2}>2 \mathrm{~mL} \cdot \mathrm{L}^{-1}$ ) as well as with regard to suboptimal oxygen and salinity conditions - URV (salinity $<11 \%$ and $\mathrm{O}_{2}<2 \mathrm{~mL} \cdot \mathrm{L}^{-1}$ ).

The hydrographic data set was used to construct horizontal fields of the thickness of suitable or unsuitable reproduction layers by a multi-dimensional linear function which is determined by a multiple regression analysis using the least square criteria

$$
F(x, y)=\sum_{i=1}^{N} \sum_{j=1}^{N} A_{i j} \times x^{(i-1)} \times y^{(j-1)}
$$

where $F(x, y)$ - grind point position; $A_{i j}$ - layer thickness between salinity $11 \%$ and $\mathrm{O}_{2} 2 \mathrm{~mL} \cdot \mathrm{L}^{-1}, x$ and $y$ are positions in longitudinal and latitudinal direction.

For the presently reported analysis of the fields of the reproduction layers it was assumed that a horizontal trend of the data could be approximated by the above-mentioned formula fitted to the observed spawning layer thickness values $A_{i j}$ using a multiple regression scheme. Applying this method a unit array configuration with a horizontal resolution of $5 \mathrm{~km}$ was provided for depths $>80 \mathrm{~m}$, with each grid point $F(x, y)$ being representative for the suitable- (salinity $\left.>11 \% ; \mathrm{O}_{2}>2 \mathrm{~mL} \cdot \mathrm{L}^{-1}\right)$ or unsuitable $\left(\mathrm{O}_{2}<2 \mathrm{~mL} \cdot \mathrm{L}^{-1}\right.$; salinity $<11 \%$ ) layer thickness centred around it. The SRV or URV of the Central Gotland Basin area were calculated for each of the surveys by simply integrating the fields of the reproduction layer thicknesses horizontally.

Hydrological regime characteristics. Presentations of long-term hydrological regime changes in the southern and central Gotland Basin are based on data from stations BY15A and BY9A (BIOR hydrographic monitoring). In order to relate cod egg vertical distribution with SRV and URV, water density profiles during cod spawning timing February-August were constructed. Water densities were calculated according to Gills (1982).

Estimation of annual cod recruitment and stock abundance in the Gotland Basin. Annual indices of the recruitment of cod, Gadus morhua, and adult cod (ages 3+) stock were calculated from Latvian research surveys in the southern and central Gotland Basin within 1975-2011. As the surveys are carried out in February-March direct estimation of the spawning stock is not appropriate because the cod spawning time shifted from spring to summer months (Wieland et al. 2000).

During 1975-2011, a total of 1181 single trawl hauls were carried out. Although the surveys were standardised to the new TV3 trawl, the area coverage varied. The number 
of hauls used was separated by years, areas (southern and central Gotland), and depth strata (DSTR): 21-40 m, 41-60 $\mathrm{m}, 61-100 \mathrm{~m}, 101-120 \mathrm{~m}$, and 121-140 m. Nine hauls carried out below $20 \mathrm{~m}$ depth and a few hauls carried out in 1992 were excluded from the analyses because of insufficient area coverage. An abundance index for the age groups 1 and $3+$ for each year was calculated, first, by calculating the mean number of the actual catch in each year, area, and DSTR combination. Then those mean strata numbers where multiplied by the coefficients of the area for the corresponding DSTR to obtain an estimated abundance index for each strata. Estimated indices then were averaged for each year.

The influence of the suitable reproductive volume, the unsuitable reproduction volume, the oxygen saturation at $11 \%$, and the abundance index of age group $3+$ on the abundance of the age 1 was analysed by multiple regression analysis in software R 3.0.2. (R Core Team 2013).

\section{RESULTS}

Comparison of SRV and URV estimates by two methods for the Gotland Basin. Regression analysis between two SRV and URV volume calculation methods generally showed that there is a strong correspondence between estimates obtained from 2 single stations in the centre of the basin and estimates obtained taking into account spatial heterogeneity of salinity and oxygen content (Fig. 3). The regression is highly significant $(P<0.0001)$ and explains $91 \%$ of variation. Largest deviations $(15 \%-23 \%)$ were observed during North Sea/Kattegat water advection into the Basin in 1977 and 1995, when the dynamics of water mass transport was the highest. Transects obtained during inflow periods show that in the eastern part of the basin, the isohaline $11 \%$ is located shallower and the isooxygen of $2 \mathrm{~mL} \cdot \mathrm{L}^{-1}$ more deeper than in the western part of the basin, i.e., the influence of the inflows was the highest in the eastern part of the basin. This confirms that inflowing North Sea/Kattegat water moves along the eastern slope of the Gotland Basin corresponding to the general circulation pattern in the Baltic (Lehmann and Hinrichsen 2002, Elken and Matthäus 2008).

During the stagnation periods, the differences were much smaller-from $1 \%$ to $8 \%$ and the isohalines as well as the isooxygens were more evenly distributed in the west-east direction.

Vertical distribution of SRV. A historical overview of the dynamics of SRV as well as of URV volumes revealed different trends within different areas of the Gotland Basin (Fig. 4).

In the southern Gotland Basin, the SRV volumes were observed more frequently and for longer time periods. Usually they were ranging from $90 \mathrm{~m}$ depths to the bottom $(120 \mathrm{~m})$. Until the mid 1980s this spatial pattern was maintained. The frequency of the occurrence of the SRV was decreasing from the southern basin towards the north where it was registered very seldom. It can be clearly seen that periods of the SRV existence in the southern Gotland Basin coincide with Kattegat water advection into the Baltic. Only strong inflows (such as in 1964, 1970, 1976, 1977, and 1993) were able to significantly improve

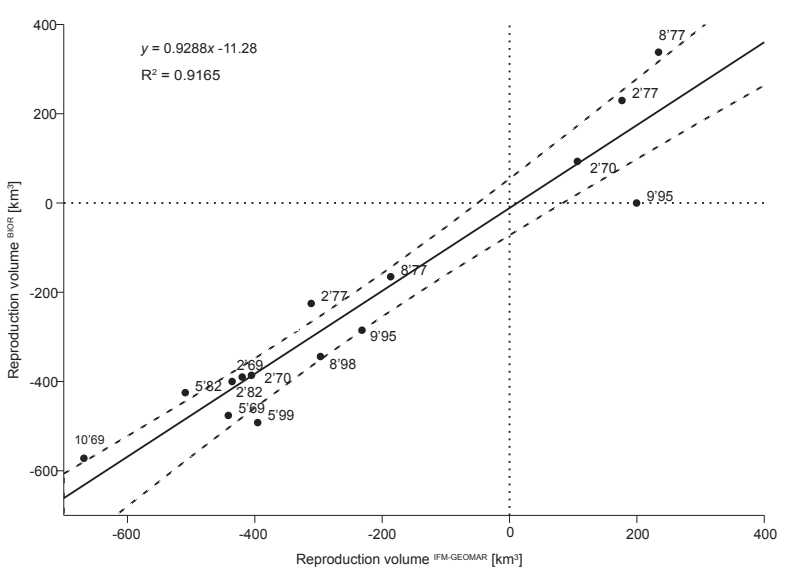

Fig. 3. Comparison of two methods of estimation of reproduction habitat for Baltic cod, Gadus morhua, in Central Gotland Basin; Institute of Food Safety, Animal Health and Environment (BIOR, Latvia) estimates based on two stations BY15A and 43; Leibnitz Institute of Marine Sciences (IFM-GEOMAR) estimates based on two transects with four oceanographic stations in each; Positive values represent suitable reproduction volume (SRV), negative values represent unsuitable reproduction volume (URV)

the hydrological situation by providing favourable conditions for cod spawning in the central Gotland Basin. In the southern Gotland Basin, the URV develops mainly during time periods between inflows, while in the Central Gotland Basin it was observed almost during all the years. Usually URV was recorded in depths from 65 to $110 \mathrm{~m}$ but an exceptionally long stagnation period after the mid 1980s led to an extension of zones from about $90 \mathrm{~m}$ to the deepest part of the basins in the early 1990s.

The major inflow of 1993 reached the Gotland Basin in 1994 and significantly influenced the hydrological regime. In the central Gotland Basin an increased suitable reproduction volume was generated from approximately $130 \mathrm{~m}$ depth down to the bottom. Such situation was not observed during previous periods.

As the SRV describes the limiting oxygen and salinity values for egg survival, it is very important to understand how this potential volume can be utilized for egg development, i.e., in which layers the cod eggs are floating. Available information from the Gdańsk and Gotland Basins shows that the highest abundances of cod eggs were observed in density ranges from 1008.4 to $1009.4 \mathrm{~kg} \cdot \mathrm{m}^{-3}$ (Makarchouk and Hinrichsen 1998). Density profiles in combination with observations of the distribution of unsuitable and suitable reproduction layers indicate that only in the southern Gotland Basin vertical egg distribution coincides sufficiently with the salinity and oxygen conditions for their successful development (Fig. 5). In the central Gotland Basin, eggs were usually exposed to insufficient oxygen conditions with the exception of 1976 and 1977, partly also in 1985. Analysis of the density and SRV profiles revealed that SRV in the central Gotland Basin in 1994 below $130 \mathrm{~m}$ could not contribute to successful egg development because the eggs had higher neutral buoyancy. 

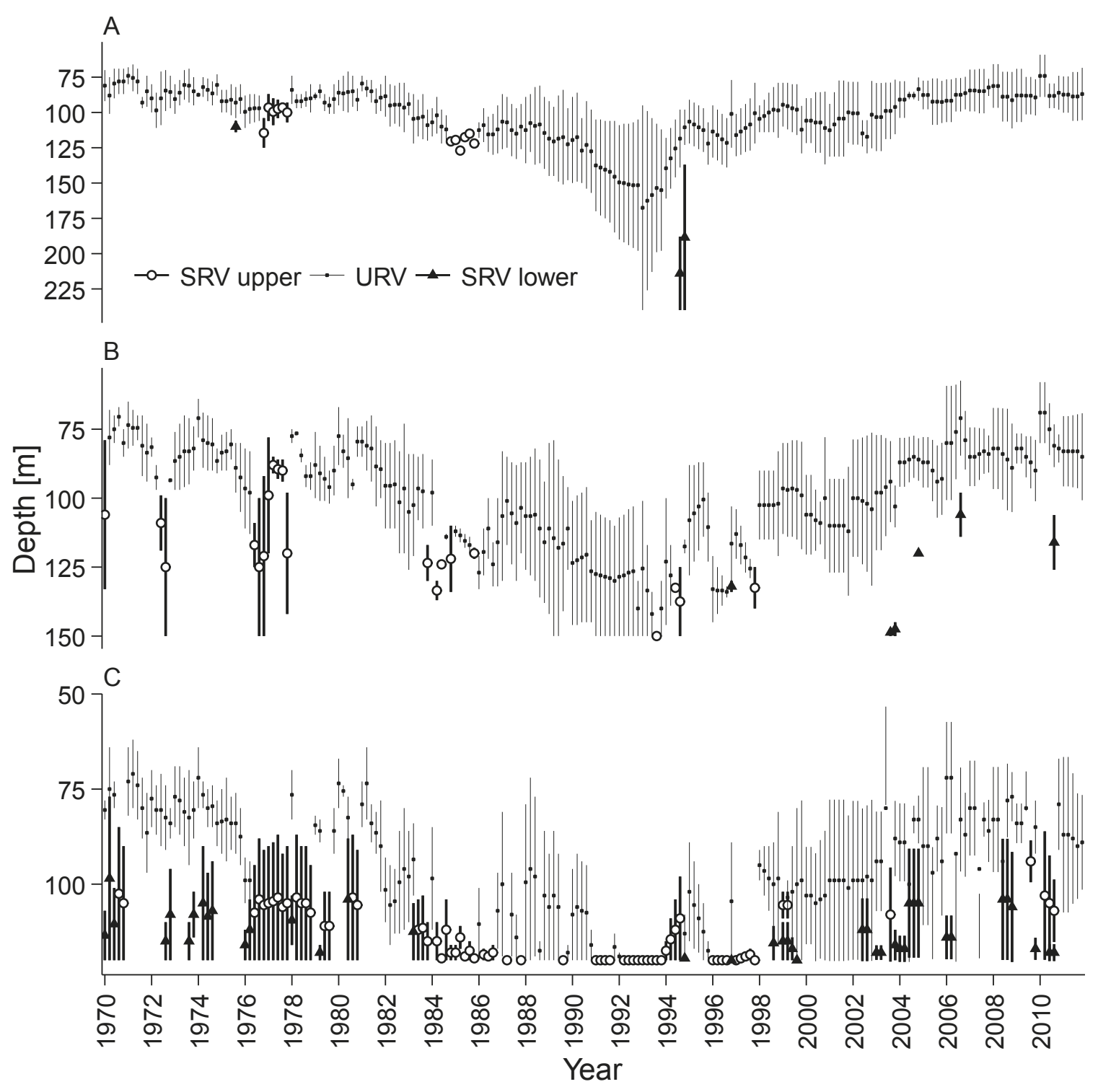

Fig. 4. Vertical distribution of suitable (SRV) and unsuitable (URV) reproduction volumes for Baltic cod, Gadus morhua, in the Gotland Basin (February, March, May, and August); Central Gotland Basin, station BY-15A (A), Central Gotland Basin, station 43 (B), Southern Gotland Basin, station BY9A (C); SRV lower = situation when suitable reproduction volume is located below the intermediate low oxygen layer $\left(<2 \mathrm{~mL} \cdot \mathrm{L}^{-1}\right)$, SRV upper $=$ situation when suitable reproduction volume developed above low oxygen $\left(<2 \mathrm{~mL} \cdot \mathrm{L}^{-1}\right)$ layer

It is generally assumed that larger SRV have higher oxygen contents than smaller ones. However, during periods of unstable and highly variable environmental conditions in the Gotland Basin it is necessary to take into account real oxygen conditions in a quantitative way. We have chosen the oxygen values at specific salinity $11 \%$ and depth of isohaline of $11 \%$ (Fig. 6). The post-1985 stagnation period was dominated by a decrease in salinity reaching down into the deep layers, so that the depth of the $11 \%$ isohaline was about $200 \mathrm{~m}$ in 1992. In previous stagnation periods only minor decreases in salinity occurred (during 1952-1980 the 11\%o isohaline never went below $110 \mathrm{~m}$ ) and the salinity regime was restored by each inflow. The isohaline depth moved upward again after the 1993 inflow but the 2003 inflow restores it on depths $80-110 \mathrm{~m}$ as in 1952-1980.
A strong increase of the oxygen contents was observed during the inflow periods 1972, 1976-1977, 1980, 1994, and 2003 while during the stagnation periods, oxygen decreased down to $0 \mathrm{~mL} \cdot \mathrm{L}^{-1}$. An increase in oxygen content observed in 1984-85 and after 2009 was apparently caused by other reasons e.g., vertical water convection or less saline water inflow. The water density at the isohaline $11 \%$, changes from 1009.1 to $1009.4 \mathrm{~kg} \cdot \mathrm{m}^{-3}$ being in range of supporting cod egg neutral buoyancy. However, during longest stagnation period 1986-1993 densities exceed the egg neutral buoyancy ranges (Fig. 6).

Recruitment relations with environmental conditions in the Gotland Basin. The demersal trawl surveys show highly variable abundance of age group 1 cod between single hauls in the Gotland Basin in the late 1970s and during 2002-2007 (Fig. 7). Higher abundance and variations 


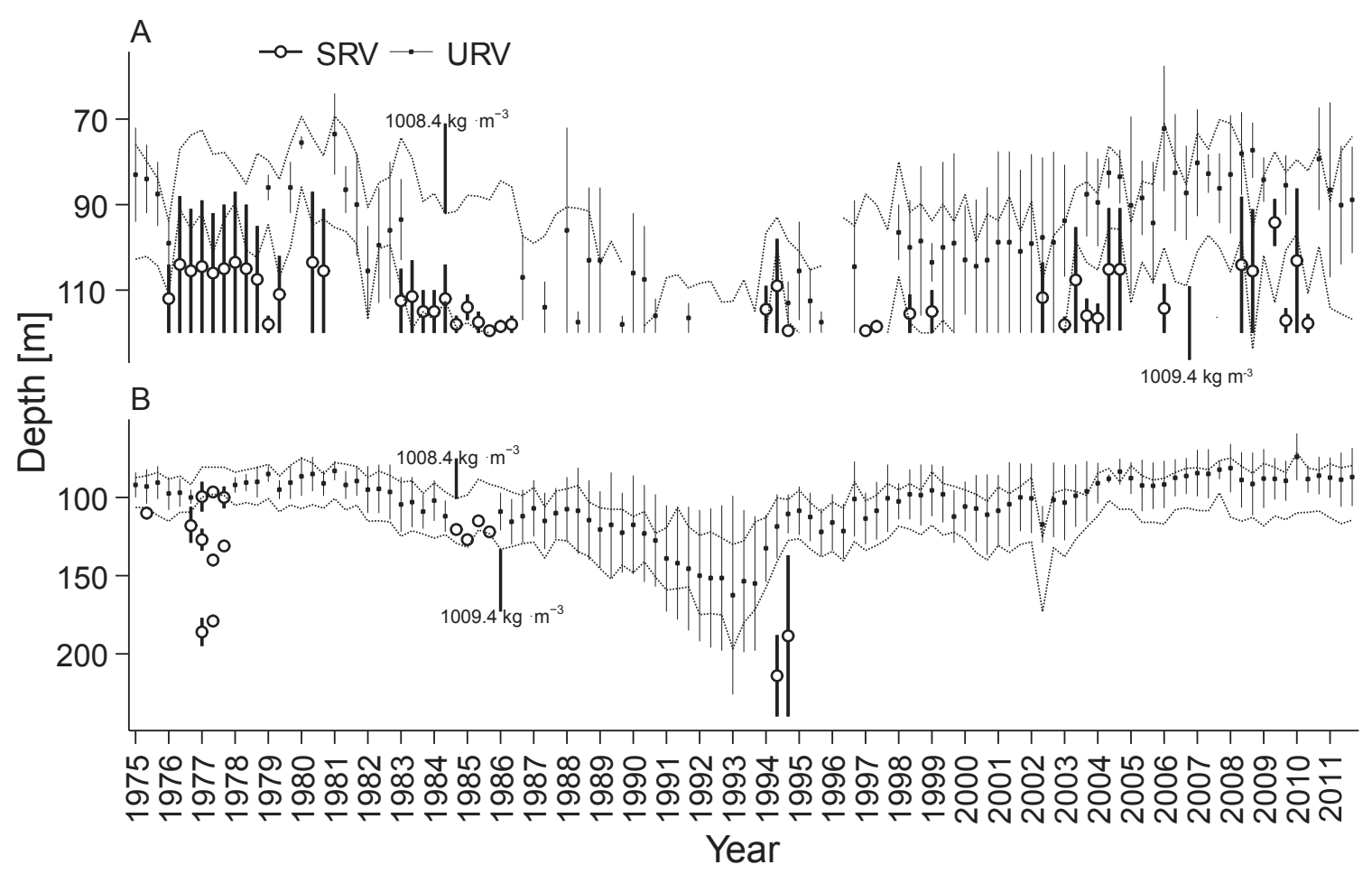

Fig 5. Water densities and vertical distribution of the suitable reproduction volume of Baltic cod, Gadus morhua, during March, May, and August in the Southern Gotland Basin (A) and in the Central Gotland Basin (B); Dotted isolines indicate water density range $\left(1008.4-1009.4 \mathrm{~kg} \cdot \mathrm{m}^{-3}\right)$ where cod eggs have neutral buoyancy; SRV = suitable reproduction volume, $\mathrm{URV}=$ unsuitable reproduction volume

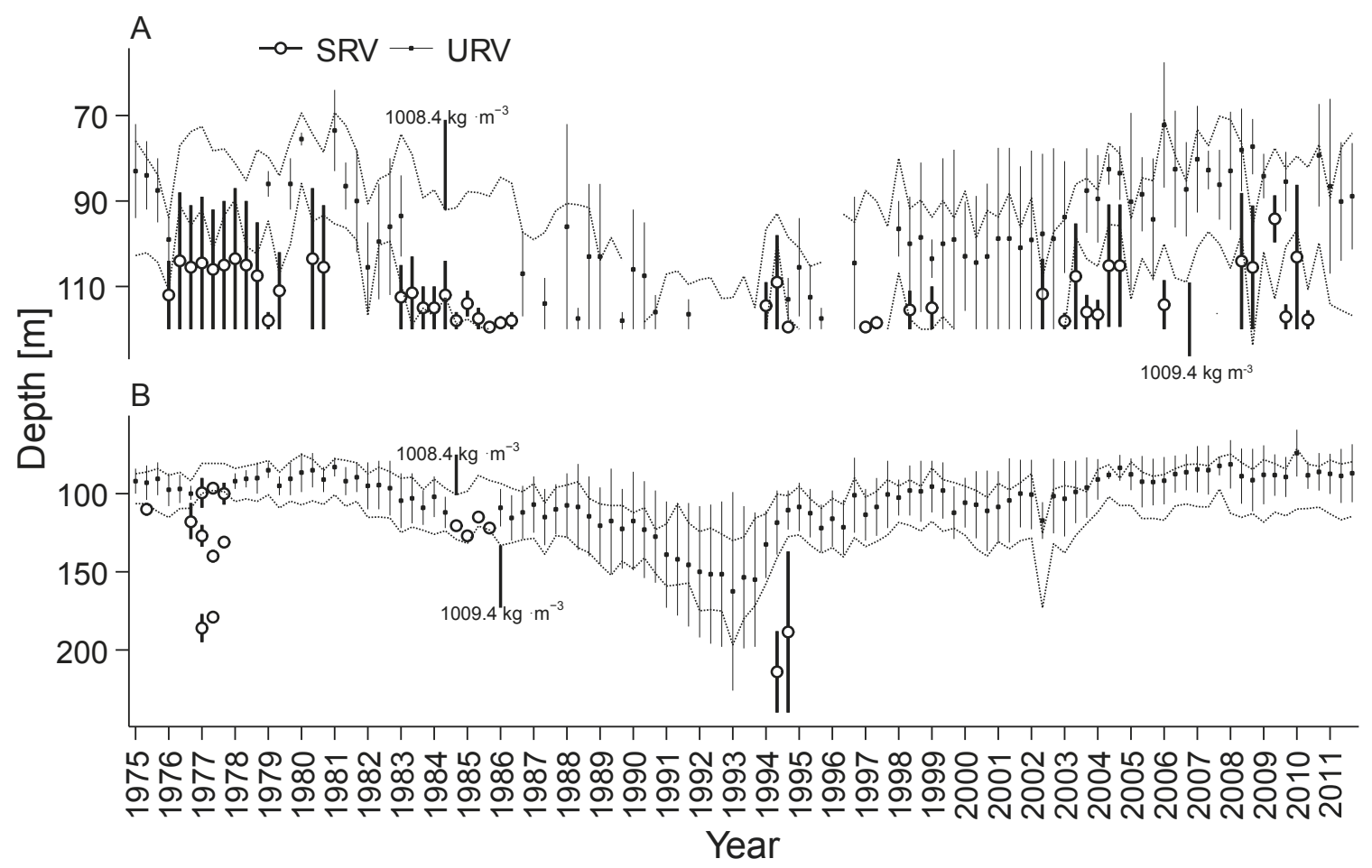

Fig. 6. Long-term changes in the depth of isohaline $11 \%$ o (A), oxygen saturation $(\mathbf{B})$ and water densities $(\mathbf{C})$ at isohaline $11 \%$ in the Central Gotland Basin 
are recorded in years when in the southern Gotland Basin sufficient conditions for successful egg development were present. Estimated age group 1 abundance indices point out that year classes 1976, 1978, 1980-1982, 2001, 2003, and 2006 are above long term mean value (Fig. 8). The exceptionally high abundance of juvenile cod occurred in 1976 when one of strongest North Sea/Kattegat water inflows (December 1975-January 1976) into the Baltic in recent history was observed.

The relation between cod recruit abundance index at age 1 and the URV and SRV in the Southern Gotland Basin was examined (Fig. 9). Although the relation was significant there were several outlying years. Year class- es 1976 and 1978 showed extremely high abundance in similar environmental situation compared with 1980 and 1977. Additionally a very low recruitment abundance index (below 25) was observed during 1992-1999 when the reproduction conditions varied from $-149 \mathrm{~km}^{3}$ (URV) to $+50 \mathrm{~km}^{3}(\mathrm{SRV})$ and the adult cod (ages $3+$ ) stock abundance was lowest in the southern Gotland Basin (Fig. 10). Hence, if there were sufficient environmental conditions for successful reproduction available, the recruit abundance was low due to less sufficient spawner abundance. In years like for example 1999 when the adult fish stock was high the offspring abundance was limited by suboptimal reproductive conditions.

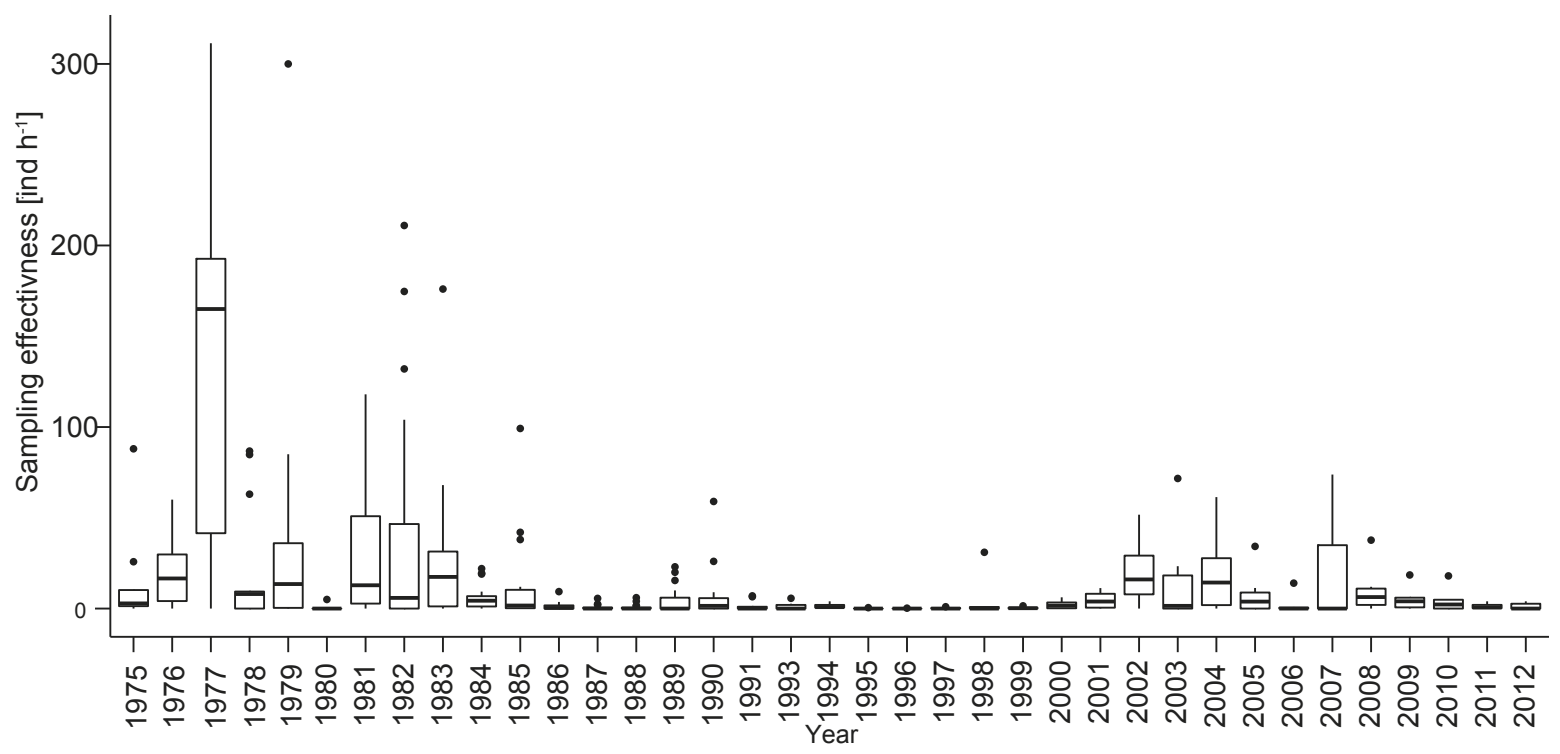

Fig. 7. Mean number of age group 1 of Baltic cod, Gadus morhua, from single hauls in research surveys in the Gotland Basin

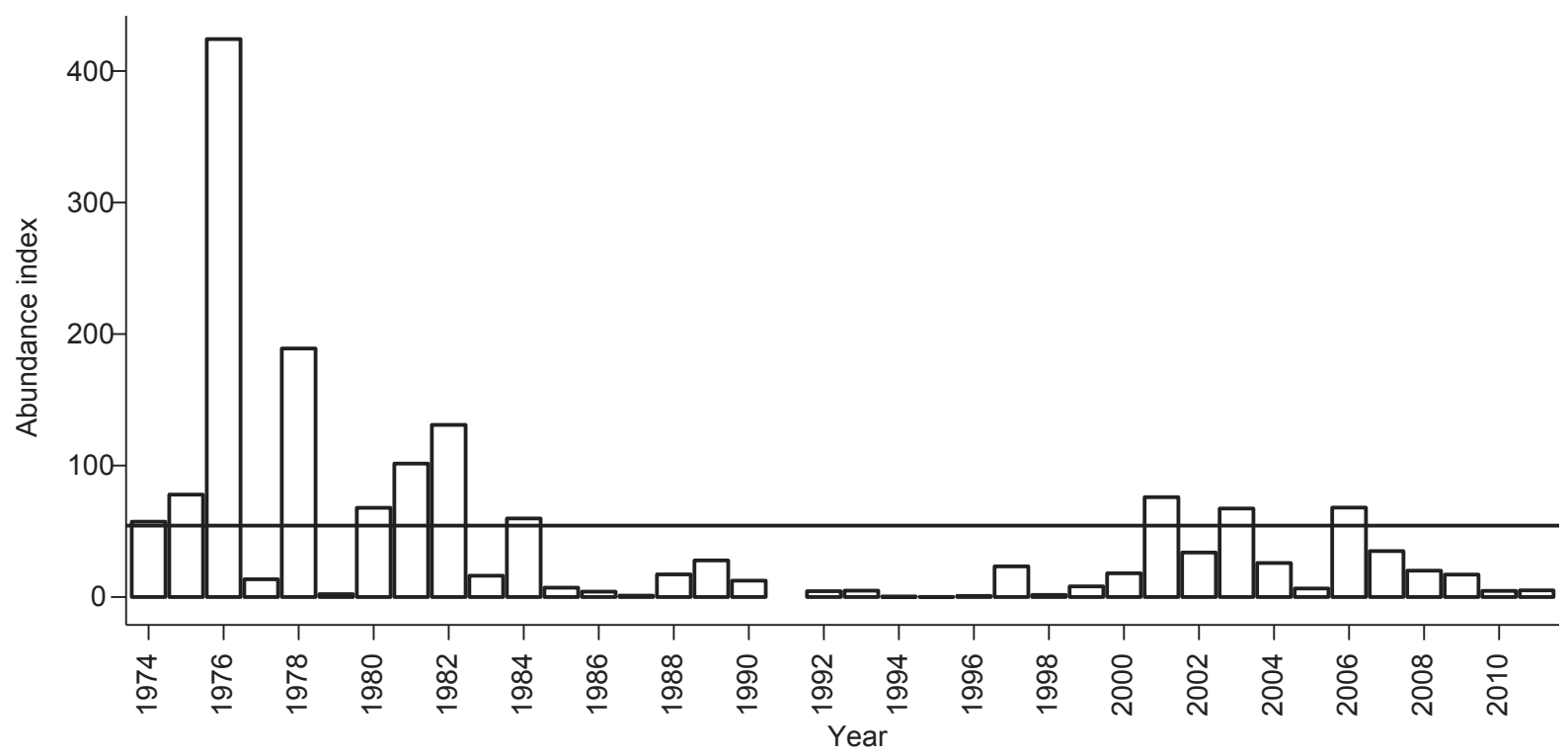

Fig. 8. Estimated abundance annual index of age group 1 of Baltic cod, Gadus morhua, based on research surveys in the Gotland Basin; Horizontal line indicate the age group 1 abundance index long term mean value $=54.3$ 


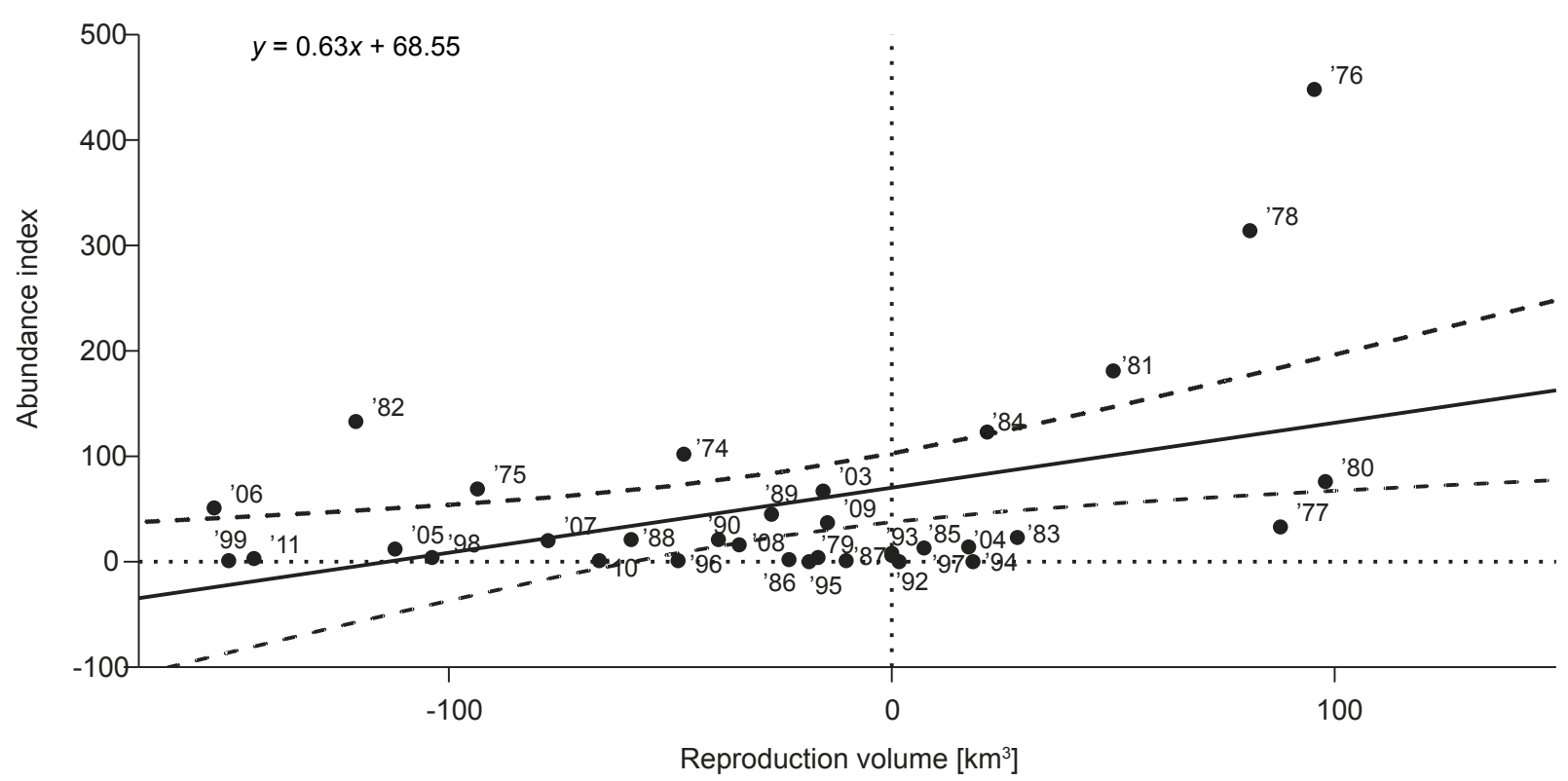

Fig. 9. Dependence of the recruitment at age 1 of Baltic cod, Gadus morhua, from suitable reproduction volume (positive values) and unsuitable reproduction volume (negative values) within May-August in the Southern Gotland Deep; Dashed line represents 95\% confidence limits; Linear regression diagnostics $\left(P=0.009, F=7.73, \mathrm{df}=32, R^{2}=0.19\right)$

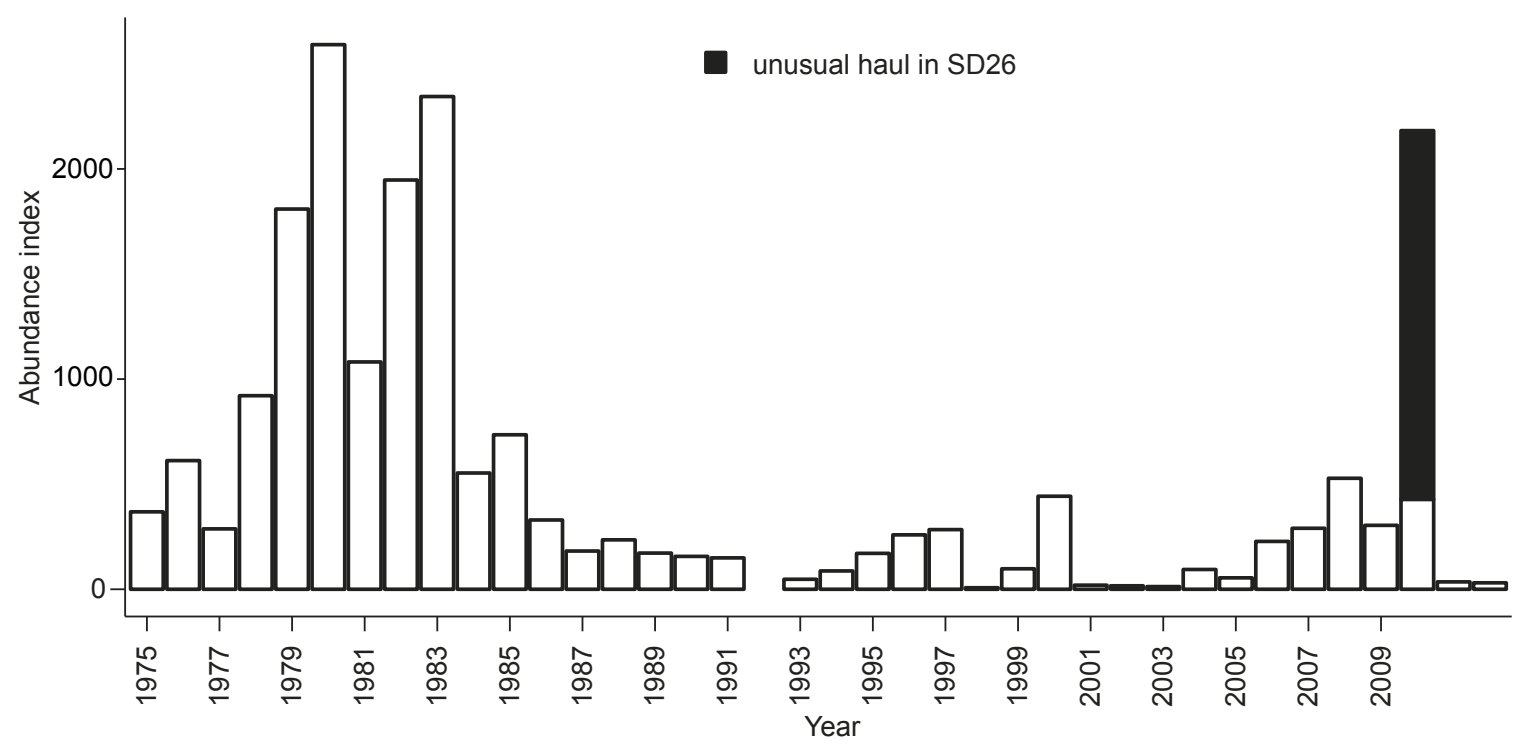

Fig. 10. Estimated abundance annual index of the age group 3+ Baltic cod, Gadus morhua, based on research surveys in the Gotland Basin

The environmental factors identified and described above, were incorporated into stock recruitment relation analyses. The following factors were included in the analyses:

- SRV as the mean value of May and August;

- URV as the mean value of May and August;

- Oxygen at 11\%o salinity in the southern Gotland Basin;

- Stock abundance index from research surveys in March-April.

The relation and factor significance was explored by multiple linear regression analysis. Stock abundance in all trial runs appeared to be insignificant and therefore was excluded from the model.

The diagnostics of the multiple linear regression analyses is given in Table 1. The statistical model for the whole time series (1975-2011) in the Central Gotland Basin reveal that the significant factor is only SRV in MayAugust. In the southern Gotland Basin the mean values of SRV and URV in May-August are significant. The oxygen saturation at $11 \%$ is significant only for the period 1986-2011. 
Table 1

Diagnostics of multiple factor stock recruitment analysis of cod, Gadus morhua

\begin{tabular}{|c|c|c|c|c|c|c|}
\hline Basin & Period & Factor & Coefficient & $\begin{array}{l}P \text {-value of } \\
\text { coefficients }\end{array}$ & $\begin{array}{c}\text { Explained } \\
\text { variation [\%] }\end{array}$ & $\begin{array}{c}P \text {-value of } \\
\text { model }\end{array}$ \\
\hline \multirow[t]{2}{*}{ Gotland CB } & $1975-2011$ & (Intercept) & 2.169 & $<0.001$ & 10.4 & 0.031 \\
\hline & & SRV_MA_CG & 0.020 & 0.031 & & \\
\hline \multirow[t]{5}{*}{ Gotland SB } & 1975-2011 & (Intercept) & 1.554 & 0.004 & 14.6 & 0.028 \\
\hline & & URV_MA_SGT & -0.009 & 0.085 & & \\
\hline & & SRV_MA_SGT & 0.024 & 0.013 & & \\
\hline & 1986-2011 & (Intercept) & 3.207 & $<0.001$ & 13.0 & 0.043 \\
\hline & & Oxy_Aug_SGT & -0.760 & 0.043 & & \\
\hline
\end{tabular}

Gotland CB = Central Gotland Basin, Gotland SB = Southern Gotland Basin, SRV_MA_CG = mean value within May-August of the suitable reproduction volume in the Central Gotland Basin, URV_MA_SGT = mean value within May-August of the unsuitable reproduction volume in the Central Gotland Basin, SRV_MA_SGT = mean value within May-August of the suitable reproduction volume in the Central Gotland Basin, Oxy_Aug_SGT = oxygen saturation at 11\%o isohaline in August in Southern Gotland Basin.

\section{DISCUSSION}

The presented analyses revealed that the main factor determining the dynamics of suitable water masses for cod reproduction in the Gotland Basin is the water advection from the North Sea/Kattegat. Major inflows into the Baltic usually take place in the period from August to April, in $60 \%$ of the cases from November through January (Matthäus 2006). The hydrological changes in the Gotland Basin usually occur 6-9 months after an inflow was registered in the Bornholm Basin, respectively during May-August (Kaleis 1977). Oxygen is mainly renewed by inflows and is depleted due to biochemical processes (Kaleis 1989). Although the present comparison of SRV and URV calculation by two methods covered only $15 \mathrm{ob}-$ servations, based on statistical test we can conclude that single point estimates adequately quantify the suitable and unsuitable reproduction volumes and thus similar to the Bornholm Basin can be used for estimation of the reproduction habitat (MacKenzie et al. 2000). This obviously is related to more even distribution of salinity and oxygen across the Gotland Basin (Bagge and Thurow 1994).

The egg survival strongly decreases if temperature is below $2^{\circ} \mathrm{C}$ (Wieland et al. 1994). As the cod reproduction in the Gotland Basin takes place in deep layers, where the ambient temperature regime shows no pronounced annual fluctuations and varies in the range of $3.2-6.6^{\circ} \mathrm{C}$. The direct lethal effects on cod egg survival and on hatching rate are expected to be limited.

We have identified several environmental parameters (URV, SRV, and oxygen saturation at specific salinity-11\%) which could influence the reproduction success of cod. The oxygen saturation in deep layer is one of the key parameters that influence formation of the SRV. The assessment of the long-term development of Baltic Sea oxygen concentration and of oxygen saturation reveals a significant negative trend since the 1950s (Hinrichsen et al. 2011). Additionally in the Gotland Basin the salinity limiting the formation of optimal cod egg development conditions, especially in stagnation period during 19821993 when water exchange with North Sea/Kattegat was not observed.
The SRV estimates assume $100 \%$ and $0 \%$ egg survival at oxygen concentrations above and below $2 \mathrm{~mL}$. $\mathrm{L}^{-1}$, respectively. In reality, laboratory experiments show that cod egg survival increases with increasing oxygen concentration in the range of $2-5 \mathrm{~mL} \cdot \mathrm{L}^{-1}$, and varies independently of oxygen concentration in the range of 5-9 $\mathrm{mL} \cdot \mathrm{L}^{-1}$ (Wieland et al. 1994). Taking into account that the buoyancy of cod eggs varies with egg size and lipid content, both of which are related to the size and condition of females as well as to batch size (Kjesbu et al. 1992, Nissling and Vallin 1996), the actual oxygen conditions inside the SRV or URV should be considered.

In the recent decades the survived cod eggs have been observed at development stages 3 and 4 (egg development stage scale according Rass and Kazanova 1966) in 1995, 1997, 1998, 2001, 2003-2005, 2007, and 2008-2010 showing that eggs can successfully develop under unsuitable spawning conditions (A. Makarchouk personal communication). It was also found a statistically significant relation between egg survival index (Grauman 1984) and the SRV : URV relation in the Gotland Basin $\left(R^{2}=0.50\right.$; $F=14.1 ; P=0.002)$ suggesting that URV like SRV can be used as an ecological indicator for egg survival probability. However, it appears to be too premature now to re-define the suitable reproduction volume concept. Information on water densities where cod eggs have been distributed is variable between seasons, hydrographic regimes, and spawning sites. They also differ between experimental and field observations (Nissling et al. 1994, Nissling and Vallin 1996, Thorsen et al. 1996, Wlodarczyk and Horbowa 1997, Makarchouk and Hinrichsen 1998). More buoyant eggs have lower chances to be exposed to low oxygen conditions and therefore have higher chances to survive. Field samplings in the Bornholm Basin revealed a strong linear relation between the egg size and the ambient water densities higher than $1008 \mathrm{~kg}^{-3} \mathrm{~m}^{-3}$ (Wlodarczyk and Horbowa 1997). Therefore, egg size can be regarded as one of the most significant factors determining the vertical egg distribution. Grauman (1969a) found that the proportion of large eggs increases with increasing female size (from $42 \%$ for $36-40 \mathrm{~cm}$ females to 
$85 \%-89 \%$ for $>66 \mathrm{~cm}$ ). For the majority of females the egg size is also dependent on the batch number (Nissling et al. 1994). Probably due to this, spawned egg sizes for all three areas (Bornholm, Gdańsk, and Gotland) show a seasonal trend-with the egg size gradually decreasing from April to August (Grauman 1969b). This trend may also be explained by size/age specific timing of spawning with large females spawning earlier (Tomkiewicz and Köster 1999, Kraus et al. 2002).

Analysis of the density profiles revealed that in general the density decreased in a given depth during cod spawning season (March-August). This is obviously related to the seasonality of inflows (Matthäus and Nausch 2003) and water dynamics in the deep layers, i.e., it means that eggs in spring can be distributed more upwards compared to the summer months. Taking into account the egg size of cod, the specific vertical distribution under such specific environmental conditions in the Gotland Basin only eggs from older females can have higher possibility of survival (Nissling et al. 1994, Wlodarczyk and Horbowa 1997).

Changes in the hydrographic situation in the central Gotland Basin during 1994 when a high SRV was observed at depths below $130 \mathrm{~m}$, did not significantly influence cod recruitment. Density profiles show that eggs could not be exposed to layers with sufficient environmental conditions for cod egg development. Therefore this volume should be excluded from later stock recruitment relation inspection.

It is well known that spawning cod prefers higher salinity and higher oxygen regimes (Lablaika and Lishev 1964, Tiews 1976, Tomkiewicz et al. 1998). During spawning mature cod can re-distribute from the central to the southern Gotland Basin. Also spawning cod migrations from the Gotland to the Bornholm Basin have been described during stagnation periods (Lišev and Lablajka 1989). Additionally, the environment where spawning of cod takes place does not always correspond to the conditions necessary for egg survival. Spawning cod has been observed at salinity of $9.5 \%$ and oxygen $1.5 \mathrm{~mL} \cdot \mathrm{L}^{-1}$ (Plikš and Kalejs 1990, Neuenfeldt et al. 2009, Schaber et al. 2011). In such situation cod eggs have low probability to survive.

Changes in the timing of cod spawning and extended maturation in the 1990s as well as higher possibilities of westward spawning migrations due to the stagnation in the Gotland Basin suggest that surveys in March-April may not reflect adequately the distribution of the spawning stock (Wieland et al. 1994, Baranova et al 2011).

Analyses of the period from the end of the 1970s also reveal that under variable environmental conditions cod recruitment in the Gotland Basin is mainly determined by environmental factors and only to a less extent by the adult fish or potential spawning stock size. This is also confirmed by the distribution of juvenile fish in different parts of the basin. In the southern Gotland Basin the age group 1 cod shows more stable concentrations while in the central Gotland Basin high abundances were registered in specific periods only. Nevertheless, a significant correlation was found between juvenile abundance indices in the southern and in the central Gotland Basin but correlation with the neighbouring the Gdańsk Deep was poor for both areas (Kondratowich and Lablaika 1989). This suggests that migration of juvenile fish outside the spawning basin was limited. However, based on hydrodynamic model simulations in years with high south-west wind energy there is a possibility of cod larvae dispersal to the southern Gotland Basin (Aro et al. 1992, Hinrichsen et al. 2001).

In southern Gotland spawning grounds, a small but relatively regularly suitable reproduction volume was formed during 2006-2012 e.g., in years without major North Sea/Kattegat water inflows. Obviously this is related to increase of intensity of baroclinic (or summer) inflows (Matthäus et al. 2008). The exceptional baroclinic inflows were reported in summer/autumn 2002, 2006, and 2009-2010 (Nausch et al. 2014). Due to this in the eastern Baltic spawning grounds in the recent years there is an increase of salinity and decrease of oxygen saturation in the intermediate water layers that allows the formation of small suitable reproduction volume. Earlier such situation obviously was observed also in 1985 .

\section{ACKNOWLEDGEMENTS}

We wish to thank Viesturs Berzins for extracting BIOR oceanographic monitoring data and discussions on longterm salinity and oxygen regime changes in the Gotland Basin and Andrei Makarchouk for recent data and information on cod egg occurrence in ichthyoplankton samples of the Gotland Basin. We thank also Erik Smedberg from the Baltic Nest Institute, Baltic Sea Centre, Stockholm University for his technical assistance during preparation of the manuscript.

\section{REFERENCES}

Anonymous 2013. Report of the Baltic Fisheries Assessment Working Group (WGBFAS). ICES Headquarters, 10-17 April 2013. ICES CM 2013/ACOM: 10.

Aro E., Myrberg K., Bagge O., Bay J. 1992. Estimation of Baltic cod eggs and larvae drift in the southern Baltic in July-August 1991 by a two-layer, two-dimensional linear flow model: Sensitivity tests and verification of the model. CM 1992/J: 5.

Bagge O., Thurow F. 1994. The Baltic cod stock: Fluctuations and possible causes. ICES Marine Science Symposia 198: 254-268.

Bagge O., Thurow F., Steffensen E., Bay J. 1994. The Baltic cod. Dana 10: 1-28.

Baranova T., Müller-Karulis B., Šics I., Plikshs M. 2011. Changes in the annual life cycle of eastern Baltic cod during 1950-2010. ICES CM 2011/R: 10.

Berner M., Müller H., Nehring D. 1989. The influence of environmental and stock parameters on the recruitment of cod stock to the east and west of Bornholm described by regression equations. Rapports et Proces-verbaux des Réunions. Conseil International pour l'Éxploration de la Mer 190: 142-146.

Elken J., Matthäus W. 2008. Baltic Sea Oceanography. Pp. 379-386. In: The BACC Author Team (eds.) Assessment of climate change for the Baltic Sea basin, Annex A.1.1. Springer-Verlag, Berlin, Heidelberg. 
Gill A.E. 1982. Atmosphere-oceans dynamics. Academic Press, New York.

Grauman G.B. 1969a. Izmenenie razmerov ikry treski (Gadus morhua callarias L.) v tečenie nerestovogo sezona. [Changes of the egg size of cod (Gadus morhua callarias L.) during spawning season.] Trudy AtlantNIRO 21: 96-101. [In Russian.]

Grauman G.B. 1969b. Značenie razmera ikry Baltijskoj treski dlâ vyživaniâ èmbrionov. [Importance of the egg size of Baltic cod for survival of the embryos.] Trudy AtlantNIRO 21: 86-95. [In Russian.]

Grauman G.B. 1984. Ihtioplankton. [Ichthyoplankton.] Pp. 259-428. In: Geršanovič D.E. (ed.) Očerki po biologičeskoj produktivnosti Baltijskogo morâ. Tom 3. [Review of Baltic Sea bioproductivity. Volume 3.] Koordinacionnyj centr stran-členov SÈV. Moskva, USSR. [In Russian.]

Heikinheimo O. 2008. Average salinity as an index for environmental forcing on cod recruitment in the Baltic Sea. Boreal Environment Research 13 (5): 457-464.

Hinrichsen H.-H., Huwer B., Makarchouk A., Petereit C., Schaber M., Voss R. 2011. Climate-driven long-term trends in Baltic Sea oxygen concentrations and the potential consequences for eastern Baltic cod (Gadus morhua). ICES Journal of Marine Science 72 (6): 2019-2028.

DOI: $10.1093 /$ icesjms/fsr145

Hinrichsen H.-H., St. John M., Aro E., Grønkjær P., Voss R. 2001. Testing the larval drift hypothesis in the Baltic Sea: Retention versus dispersion caused by wind-driven circulation. ICES Journal of Marine Science 58 (5): 973-984.

DOI: $10.1006 /$ jmsc.2001.1090

Jarre-Teichman A. Wieland K., MacKenzie B.R., Hinrichsen H.-H., Plikshs M., Aro E. 1997. Stock-recruitment relationship for cod (Gadus morhua callarias L.) in the central Baltic Sea incorporating environmental variability. Archive of Fishery and Marine Research 48 (2): 97-123.

Kaleis M.V. 1977. The peculiarities of Kattegat water advection in the deep layer of the Baltic Sea. Ambio Special Report 1977 (5): 201-204.

Kalejs M.B. 1989. Kislorod [Oxygen]. Pp. 74-79. In: Davidan I.N., Savčuk O.P. (eds.) Problemy issledovaniâ i matematičeskogo modelirovaniâ èkosistemy Baltijskogo morâ. Vypusk 4. Osnovnye tendencii èvolucii èkosistemy. [Problems of research and mathematical modelling on the Baltic Sea ecosystem. Issue 4. Main trends in the ecosystem evolution.] Gidrometeoizdat, Leningrad, USSR. [In Russian.]

Kjesbu O.S., Kryvi H., Sundby S., Solemdal P. 1992. Buoyancy variation in eggs of Atlantic cod (Gadus morhua L.) in relation to chorion thickness and egg size: Theory and observations. Journal of Fish Biology 41 (4): 581-599.

DOI: $10.1111 /$ j.1095-8649.1992.tb02685.x

Kondratowich E., Lablaika I. 1989. Abundance and ecology of young cod in the Eastern Baltic in 1980-1987.
Rapports et Proces-verbaux des Réunions. Conseil International pour l'Éxploration de la Mer 190: 58-62.

Kosior M., Netzel J. 1989. Eastern Baltic cod stock and environmental conditions. Rapports et Proces-verbaux des Réunions. Conseil International pour l'Éxploration de la Mer 190: 159-162.

Köster F.W., Hinrichsen H.-H., St. John M.A., Schnack D., MacKenzie B., Tomkiewicz J., Plikshs M. 2001. Developing Baltic cod recruitment models. II: Incorporation of environmental variability and species interaction. Canadian Journal of Fisheries and Aquatic Sciences 58 (8): 1534-1556.

DOI: $10.1139 /$ cjfas-58-8-1534

Köster F.W., Hinrichsen H.-H., Schnack D., St. John M.A., MacKenzie B., Tomkiewicz J., Möllmann C., Kraus G., Plikshs M., Makarchouk A., Aro E. 2003. Recruitment of Baltic cod and sprat stocks: Identification of critical life stages and incorporation of environmental variability into stock-recruitment relationships. Scientia Marina 67 (Supl.1): 129-154.

DOI: $10.3989 /$ scimar.2003.67s 1129

Kraus G., Tomkiewicz J., Köster F.W. 2002. Egg production of Baltic cod (Gadus morhua) in relation to variable sex ratio, maturity, and fecundity. Canadian Journal of Fisheries and Aquatic Sciences 59 (12): 1908-1920. DOI: $10.1139 / \mathrm{F} 02-159$

Lablaika I., Lishev M.N. 1964. Possibilities of forecasting the distribution of stock and efficiency of fishing for Baltic cod during pre-spawning and spawning periods. ICES CM Nr. 90.

Lablaika I., Uzars D. 1983. Èkologiâ i učot čislennosti molodi treski v Vostočnoj Baltike [Ecology and abundance of cod juveniles in the Eastern Baltic]. Fischerei-Forschung 21 (3): 24-30. [In Russian.]

Lehmann A., Hinrichsen H.-H. 2002. Water, heat and salt exchange between the deep basins of the Baltic Sea. Boreal Environment Research 7 (4): 405-415.

Lišev M.N. [Lishev M.N.], Lablajka I. [Lablayka I.] 1989. Raspredelenie zapasa vostočno-baltijskoj treski $\mathrm{v}$ areale $\mathrm{i}$ formirovanie sootvetstvuûsej promyslovoj obstanovki. [Distribution of eastern-Baltic cod stock and formation of corresponding fishing conditions.] Pp. 222-228. In: Davidan I.N., Savčuk O.P. (eds.) Problemy issledovaniâ i matematičeskogo modelirovaniâ èkosistemy Baltijskogo morâ. Vypusk 4. Osnovnye tendencii èvolucii èkosistemy. [Problems of research and mathematical modelling on the Baltic Sea ecosystem. Issue 4. Main trends in the ecosystem evolution.] Gidrometeoizdat, Leningrad, USSR. [In Russian.]

MacKenzie B.R., Hinrichsen H.-H., Plikshs M., Wieland K., Zezera A.S. 2000. Quantifying environmental heterogeneity: Habitat size for successful development of cod Gadus morhua egg in the Baltic Sea. Marine Ecology Progress Series 193: 143-156.

Makarchouk A., Hinrichsen H.-H. 1998. The vertical distribution of ichthyoplankton in relation to the hydrographic conditions in the Eastern Baltic. ICES CM, 1998/R: 11. 
Margonski P., Hansson S., Tomczak M.T., Grzebielec R. 2010. Climate influence on Baltic cod, sprat, and herring stock-recruitment relationships. Progress in Oceanography 87 (1-4): 277-288.

DOI: $10.1016 /$ j.pocean.2010.08.003

Matthäus W. 2006. The history of investigation of salt water inflows into the Baltic Sea-from the early beginning to recent results. Meereswissenschaftliche Berichte No. 65 .

Matthäus W., Nausch G. 2003. Hydrographic-hydrochemical variability in the Baltic Sea during the 1990s in relation to changes during the 20th century. ICES Marine Science Symposia 219: 132-143.

Matthäus W., Nehring D., Feistel R., Nausch G., Mohrholz V., Lass H.-U. 2008. The inflow of highly saline water into the Baltic Sea. Pp. 265-309.

DOI: 10.1002/9780470283134.ch10. In: Feistel R., Nausch G., Wasmund N. (eds.) State and evolution of the Baltic Sea, 1952-2005. A Detailed 50-year survey of meteorology and climate, physics, chemistry, biology, and marine environment. John Wiley and Sons, Inc. Hoboken NJ, USA.

DOI: $10.1002 / 9780470283134$

Nausch G., Feistel R., Naumann M., Mohrholz V. 2014. Water exchange between the Baltic Sea and the North Sea, and conditions in the deep basins. HELCOM Baltic Sea Environment Fact Sheets.

Neuenfeldt S., Andersen K.H., Hinrichsen H.-H. 2009. Some Atlantic cod Gadus morhua in the Baltic Sea visit hypoxic water briefly but often. Journal of Fish Biology 75 (1): 290-294.

DOI: $10.1111 /$ j.1095-8649.2009.02281.x

Nissling A., Kryvi H., Vallin L. 1994. Variation in egg buoyancy of Baltic cod Gadus morhua and its implications for egg survival in prevailing conditions in the Baltic Sea. Marine Ecology Progress Series 110: 67-74.

Nissling A., Vallin L. 1996. The ability of Baltic cod eggs to maintain neutral buoyancy and the opportunity for survival in fluctuating conditions in the Baltic Sea. Journal of Fish Biology 48 (2): 217-227. DOI: $10.1111 /$ j.1095-8649.1996.tb01114.X

Nissling A., Westin L. 1997. Salinity requirements for successful spawning of Baltic and Belt Sea cod and the potential for cod stock interactions in the Baltic Sea. Marine Ecology Progress Series 152: 261-271.

Plikš M.A. [Plikshs M.A.], Kalejs M.B. 1990. Osobennosti raspredeleniâ treski $\mathrm{v}$ period neresta $\mathrm{V}$ Vostočnoj Baltike v 1986-1988 gg. [Peculiarities of cod distribution during spawning time in the eastern Baltic in 1986-1988.] Fischerei-Forschung 28 (2): 39-43. [In Russian.]

Plikshs M., Kalejs M., Grauman G. 1993. The influence of environmental conditions and spawning stock size on the year-class strength of the eastern Baltic cod. ICES CM 1993/J: 22.

Rass T.S., Kazanova I.I. 1966. Metodičeskoe rukovodstvo po sboru ikrinok, ličinok i mal'kov ryb. [Manual for sampling fish eggs, larvae and fry.] Izdatel'stvo Piŝevaâ promyšlennost', Moskva, USSR.
R Core Team 2013. R: A language and environment for statistical computing. R Foundation for Statistical Computing, Vienna, Austria. http://www.R-project.org

Schaber M., Hinrichsen H.-H., Gröger J. 2011. Seasonal changes in vertical distribution patterns of cod (Gadus morhua) in the Bornholm Basin, central Baltic Sea. Fisheries Oceanography 21 (1): 33-43. DOI: $10.1111 / \mathrm{j} .1365-2419.2011 .00607 . x$

Sparholt H. 1996. Causal correlation between recruitment and spawning stock size of central Baltic cod? ICES Journal of Marine Science 53 (5): 771-779. DOI: $10.1006 /$ jmsc. 1996.0098

Stigebrandt A. 1987. A model for the vertical circulation of the Baltic deep water. Journal of Physical Oceanography 17 (10): 1772-1785. DOI: 10.1175/1520-0485(1987)017<1772:AMFTVC >2.0.CO;2

Stigebrandt A., Wulff F. 1987. A model for the dynamics of nutrients and oxygen in the Baltic proper. Journal of Marine Research 45 (3): 729-757.

DOI: $10.1357 / 002224087788326812$

Thorsen A., Kjesbu O.S., Fyhn H.J., Solemdal P. 1996. Physiological mechanisms of buoyancy in eggs from brackish water cod. Journal of Fish Biology 48 (3): 457-477.

DOI: $10.1111 / \mathrm{j} .1095-8649.1996 . t b 01440 . x$

Tiews K. 1974. Futher results of studies on the spawning stock of cod in the middle Baltic Sea. Rapports et Proces-verbaux des Réunions. Conseil International pour l’Éxploration de la Mer 166: 66-82.

Tomkiewicz J., Köster F.W. 1999. Maturation processes and spawning time of cod in the Bornholm Basin of the Baltic Sea: Preliminary results. ICES CM 1999/Y: 25.

Tomkiewicz J., Lehmann K.L., St. John M.A. 1998. Oceanographic influences on the distribution of Baltic cod, Gadus morhua, during spawning in the Bornholm Basin of the Baltic Sea. Fisheries Oceanography 7 (1): 48-62.

DOI: $10.1046 /$ j.1365-2419.1998.00051.x

Wieland K., Jarre-Teichmann A., Horbowa K. 2000. Changes in the timing of spawning of Baltic cod: Possible causes and implications for recruitment. ICES Journal of Marine Science 57 (2): 452-464.

DOI: $10.1006 /$ jmsc. 1999.0522

Wieland K., Waller U., Schnack D. 1994. Development of Baltic cod eggs at different levels of temperature and oxygen content. Dana 10: 163-177.

Wlodarczyk E., Horbowa K. 1997. Size-specific vertical distribution of Baltic cod (Gadus morhua L.) eggs in the Bornholm Basin in 1993 and 1994. ICES Journal of Marine Science 54 (2): 206-212. DOI: $10.1006 /$ jmsc. 1996.0186

Received: 16 April 2014

Accepted: 29 June 2015

Published electronically: 30 September 2015 